\title{
Ordforklaringer
}

Hjertespesifikt troponin T er del av myokardcellenes kontraktile apparat. Målbare sirkulerende verdier i sammenheng med akutte brystsmerter har tidligere vært regnet som tegn på akutt hjerteinfarkt. Med nye, mer følsomme målemetoder er det observert at det kan sirkulere troponin uten at dette indikerer akutt myokardskade.

MR-undersøkelse (magnetresonansundersøkelse) av hjertet: Dette regnes som gullstandardmetoden for å vurdere kardial struktur og funksjon.

Integrert diskrimineringsindeks (IDI) måler bedring i risikodiskriminering, dvs. hvor godt en statistisk modell skiller individer med og individer uten sykdom. Dette gjøres ved å beregne endringen i de gjennomsnittlige estimerte sannsynligheter

\section{Troponin, hjertestruktur og risiko for død}

\author{
Troponin T-målinger i befolkningen gir informasjon om hjertestruktur \\ og dødsrisiko. Det viser en ny studie der tredjeforfatteren er norsk.
}

Endringer i nivået av sirkulerende troponin er et hovedkriterium for diagnosen akutt hjerteinfarkt. Ved mistanke om akutt koronarsyndrom måles troponin $\mathrm{T}$ - eller troponin I-nivået regelmessig. Under $1 \% \mathrm{av}$ befolkningen har målbare verdier med tradisjonelle målemetoder for troponin T. Med innføring av høysensitive metoder vil en større andel ha målbare verdier, men de hjertestrukturelle korrelater og den prognostiske verdi av dette ikke har vært kjent.

I en ny undersøkelse ble troponin T målt med en ny, følsom metode hos 3546 deltakere i alderen 30-65 år i en befolkningsbasert studie i USA (1). Prevalensen av målbar troponin $\mathrm{T}$ var $25 \%$, i motsetning til $0,7 \%$ med den tradisjonelle metoden. Prevalensen av målbar troponin $T$ var signifikant høyere hos menn enn hos kvinner ( $37 \%$ versus $13 \%$ ) og økte med stigende alder. Videre var venstre ventrikkels masse, målt med kardial MR-undersøkelse, en sterk determinant for troponin T-konsentrasjonen. Prevalensen av venstre ventrikkelhypertrofi steg fra $8 \%$ hos individer med troponin T-nivå $<3$ ng/l til $48 \%$ hos dem med verdier $>14 \mathrm{ng} / \mathrm{l}$.

- Troponin T var en sterk prognostisk markør, og insidensen av død i løpet 6,4 år økte fra $2 \%$ til $28 \%$ fra laveste $(<3 \mathrm{ng} / \mathrm{l})$ til høyeste $(>14 \mathrm{ng} / \mathrm{l})$ troponin T-kategori. Etter justering for konvensjonelle risikofaktorer, slik som kronisk nyresykdom, C-reaktivt protein og N-terminal pro-Btype natriuretisk peptid, var det fremdeles sterk sammenheng mellom troponin T-nivå og dødelighet. Mange personer fikk sin risiko for død reklassifisert bedømt ut fra integrert diskrimineringsindeks. Dette tyder på at testen kan gi tilleggsinformasjon av klinisk betydning, sier Torbjørn Omland, som er studiens tredjeforfatter.

- I tillegg kan disse funnene få konsekvenser for hvilke beslutningsgrenser som bør brukes for å diagnostisere akutt hjerteinfarkt. Til nå har vi brukt en flat verdi svarende til 99-prosentilen hos blodgivere, men siden denne undersøkelsen viser at troponinverdiene varierer betydelig både med kjønn og alder, vil det sannsynligvis $ø$ ke den diagnostiske presisjonen dersom alders- og/eller kjønnsjusterte beslutningsgrenser tas i bruk, sier Omland.

\section{Forskning på \\ kardiovaskulære biomarkører}

Torbjørn Omland er professor I ved Universitetet i Oslo og overlege ved Medisinsk divisjon, Akershus universitetssykehus. Samarbeidet med forskerne i Dallas Heart Study kom i stand fordi både Omland, førsteforfatter James de Lemos og annenforfatter Mark Drazner arbeidet ved Brigham and Women's Hospital i Boston i 1990-årene. Omland og de Lemos har hatt felles forskningsinteresse innen feltet kardiovaskulære biomarkører og har publisert ni artikler sammen, deriblant to i The New England Journal of Medicine (2).

\section{Erlend Hem}

erlend.hem@medisin.uio.no

Tidsskriftet

\section{Litteratur} ciation of troponin T detected with a highy sensitive assay and cardiac structure and mortality risk in the general population. JAMA 2010; 304: 2503-12.

2. Hem E. Ny sensitiv målemetode ved koronarsykdom. Tidsskr Nor Legeforen 2010; 130: 357.
1. de Lemos JA, Drazner MH, Omland T et al. Asso- for utfallet hos individer med og individer uten det aktuelle utfallet etter at den nye risikomarkøren er tatt med i modellen.

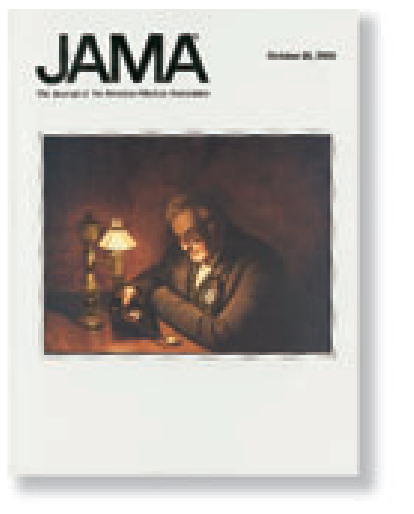

Artikkelen ble publisert 8.12. 2010 i JAMA (www.jama.com), som regnes som en av de «fem store» innen medisinsk publisering - ved siden av New England Journal of Medicine, BMJ, Annals of Internal Medicine og The Lancet

\section{Tips oss}

Erdu i ferd med å publisere eller har du nylig publisert eller har du nylig publiskrift? Send tips til erlend.hem@medisin.uio.no 